Hammond, E. C. (1958). J. gen. Microbiol. 19, 267-270

\title{
Ammonium Alginate Wool as a Filter for Collecting Micro-organisms from Large Volumes of Air
}

\author{
By E. C. HAMMOND \\ Distillers Co. Ltd., Great Burgh, Epsom, Surrey
}

SUMMARY : Ammonium alginate wool has proved to be a suitable collecting filter for estimating a small number of micro-organisms in a large volume of air.

A large supply of air free from micro-organisms is needed for certain modern commercial processes, such as submerged fermentations, which depend upon aeration and the control of infection. Consequently, it is necessary to test this air for sterility. Most methods of estimation are unsuited to lengthy tests and to large quantities of air, for instance the membrane filter (Haas, 1956), which, though efficient, offers a high resistance to airflow. Sodium alginate wool was found by Richards (1955) to be a suitable filtering material, and, as it is water-soluble, it can be dissolved for plating out; it cannot be purchased, but it is readily formed when calcium alginate is added to a solution of certain sodium salts (Higgins, 1950). Ammonium alginate is available, and is, if anything, slightly better for the purpose than the sodium salt; its ability to collect the micro-organisms from air has been tested by passing artificially infected air afterwards through a membrane filter, which showed that the alginate had collected all the organisms of the size of yeasts or mould spores, and more than $99 \%$ of the spores of Bacillus subtilis.

\section{METHODS}

Description of apparatus. The sampler designed by Richards (1955) was made of metal tubing and had cross-wires to hold the column of wool in place. The writer has used a Quickfit and Quartz B 19 cone, the wool being held by a constriction, which was blown against a carbon rod to give an internal diameter of $\frac{5}{16}$ in. (Fig. 1).

One gramme of ammonium alginate 50 denier/12 filament, garnetted waste, from Courtaulds Ltd., Cross Street, Manchester, was divided into five parts, each of which was shaped into a disk to fit into the tube, the five disks forming the filtering column. The tube was plugged at each end with non-absorbent cotton-wool and placed in a glass container, which was also plugged. The whole was autoclaved for $30 \mathrm{~min}$. at $10 \mathrm{lb}$./sq.in. An alternative method of sterilizing, in a dry oven at $110^{\circ}$ for $12 \mathrm{hr}$., was abandoned because it made the alginate wool brown and brittle. Air containing the test organism, either as an aerosol or as a dust, was blown through the apparatus at speeds varying from 1 to 5 cu.ft./min., and then through a membrane filter (Oxoid) to trap any organisms which had passed through the alginate. DuBuy, Hollaender \& 
Lackey (1945) gave an excellent description of sampling devices and their efficiencies; they recommended the atomizer bubbler, but the present writer found that it offered too large a resistance to airflow, and the membrane filter was considered more suitable.

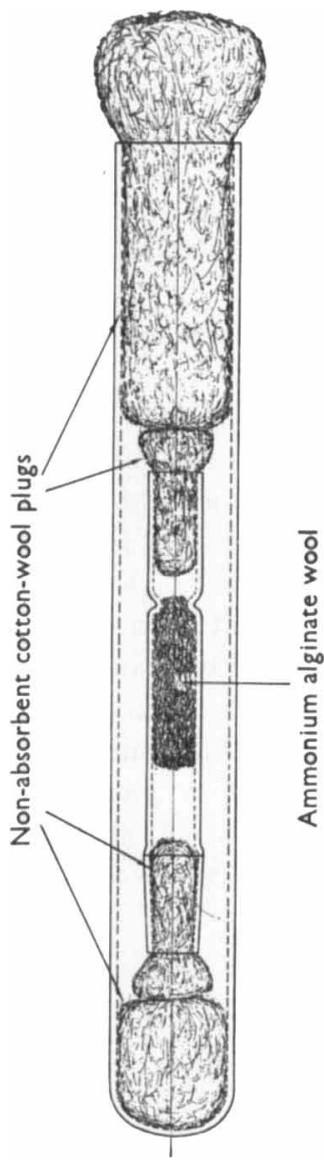

Fig. 1

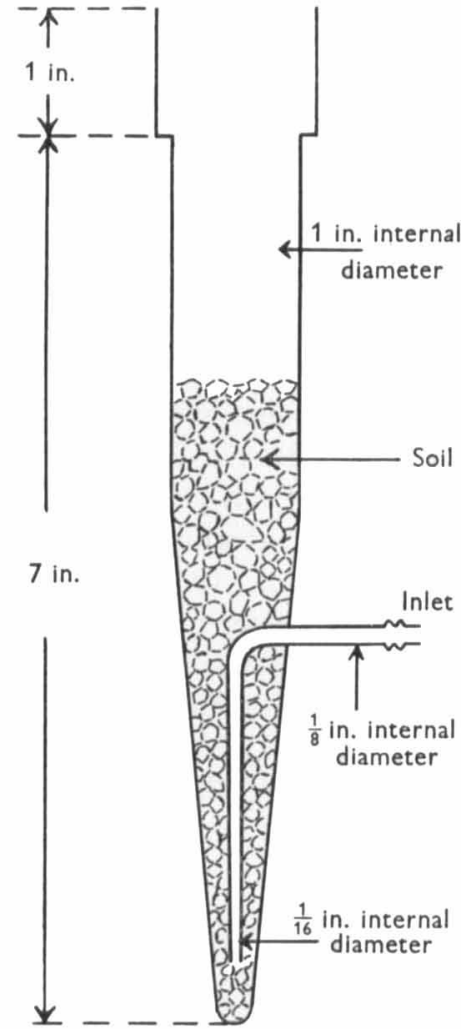

Fig. 2

Preparation of aerosol. The aerosol of the test organism was prepared by passing cold dried air through a small glass atomizer containing a heavy suspension of spores of Bacillus subtilis. The relative humidity and temperature of the effluent air were recorded.

Preparation of dust. Soil that had passed through a 20-mesh sieve, but had been retained by a 30-mesh sieve, was sterilized, inoculated with an aqueous suspension of spores of Bacillus subtilis, dried in a vacuum desiccator, and placed in the apparatus shown in Fig. 2. The velocity of air at various humidities was adjusted by means of a rotameter to cause a continuous agitation of the soil.

Plating out. By means of a sterile glass rod, the alginate wool was pushed from the tube into $40 \mathrm{ml}$. of sterile $0.5 \%(\mathrm{w} / \mathrm{v})$ dipotassium hydrogen phos- 
phate solution. (This buffer was needed because $1 \mathrm{~g}$. ammonium alginate dissolved in water and mixed with nutrient agar decreased the $\mathrm{pH}$ of the agar from $6 \cdot 8$ to $4 \cdot 6$; on such a plate the growth of Bacillus subtilis was greatly retarded, though Saccharomyces cerevisiae and a Penicillium sp. were not affected.) Samples of the phosphate solution were mixed with $20 \mathrm{ml}$. quantities of glucose nutrient agar at $45^{\circ}$ and were plated out and incubated at $30^{\circ}$ for 3 days. The Oxoid membrane was placed in $20 \mathrm{ml}$. of $0.5 \%(\mathrm{w} / \mathrm{v}) \mathrm{NaCl}$ solution in a flask with some beads and mechanically shaken for 10-15 min.; samples were then mixed with nutrient agar and plated out.

\section{RESUL'TS}

Table 1 gives the results for aerosol tests, three out of four of which showed $100 \%$ retention of spores of Bacillus subtilis by ammonium alginate wool. Table 2 gives five results for dry dusts which are representative of 27 tests carried out; all individual tests gave efficiencies greater than $99 \%$. The alginate wool must be evenly packed, for a deliberately badly packed tube gave an efficiency of only $97 \cdot 75 \%$.

Table 1. Aerosol tests with spores of Bacillus subtilis

\begin{tabular}{|c|c|c|c|c|}
\hline Filter & Total count & $\begin{array}{l}\text { Relative } \\
\text { humidity }\end{array}$ & $\begin{array}{c}\text { Temperature } \\
\text { (' } \mathrm{C} .)\end{array}$ & $\begin{array}{c}\text { Efficiency } \\
(\%)\end{array}$ \\
\hline $\begin{array}{l}\text { Alginate wool } \\
\text { Oxoid membrane }\end{array}$ & $\begin{array}{r}400,000 \\
8\end{array}$ & 60 & 29 & $99 \cdot 99$ \\
\hline $\begin{array}{l}\text { Alginate wool } \\
\text { Oxoid membrane }\end{array}$ & $\begin{array}{r}240,000 \\
0\end{array}$ & 60 & 29 & 100 \\
\hline $\begin{array}{l}\text { Alginate wool } \\
\text { Oxoid membrane }\end{array}$ & $\begin{array}{r}186,000 \\
0\end{array}$ & 60 & 29 & 100 \\
\hline $\begin{array}{l}\text { Alginate wool } \\
\text { Oxoid membrane }\end{array}$ & $\begin{array}{r}180,000 \\
0\end{array}$ & 60 & 29 & 100 \\
\hline
\end{tabular}

Table 2. Spores of Bacillus subtilis as a dry dust

\begin{tabular}{|c|c|c|c|c|}
\hline Filter & Total count & $\begin{array}{l}\text { Relative } \\
\text { humidity }\end{array}$ & $\begin{array}{c}\text { Temperature } \\
\left({ }^{\circ} \mathrm{C} .\right)\end{array}$ & $\begin{array}{c}\text { Efficiency } \\
(\%)\end{array}$ \\
\hline $\begin{array}{l}\text { Alginate wool } \\
\text { Oxoid membrane }\end{array}$ & $\begin{array}{r}240,000 \\
240\end{array}$ & 50 & 21 & $99 \cdot 9$ \\
\hline $\begin{array}{l}\text { Alginate wool } \\
\text { Oxoid membrane }\end{array}$ & $\begin{array}{r}400,000 \\
3,500\end{array}$ & 60 & $19 \cdot 5$ & $99 \cdot 13$ \\
\hline $\begin{array}{l}\text { Alginate wool } \\
\text { Oxoid membrane }\end{array}$ & $\begin{array}{r}280,000 \\
1,500\end{array}$ & 70 & $20 \cdot 5$ & $99 \cdot 46$ \\
\hline $\begin{array}{l}\text { Alginate wool } \\
\text { Oxoid membrane }\end{array}$ & $\begin{array}{r}140,000 \\
300\end{array}$ & 80 & 21 & $99 \cdot 79$ \\
\hline $\begin{array}{l}\text { Alginate wool } \\
\text { Oxoid membrane }\end{array}$ & $\begin{array}{r}400,000 \\
260\end{array}$ & 90 & 22 & $99 \cdot 94$ \\
\hline
\end{tabular}

Depth of penetration of the alginate wool column by dry spores of Bacillus subtilis. Five wads of ammonium alginate wool (each $0 \cdot 2 \mathrm{~g}$.) were placed adjacent to one another in a tube; air containing dry spores was passed, and 
each of the wads plated out. The results show that the penetration of single spores is probably logarithmic, as found by Humphrey \& Gaden (1955) in the case of a fibrous filter.

\section{CONCLUSIONS}

Ammonium alginate wool used as an air sampler is $100 \%$ efficient for organisms of diameter greater than $2 \mu$, which includes the majority of yeasts and moulds. It varied in efficiency from $99 \cdot 13$ to $99.96 \%$ with dry spores of Bacillus subtilis in concentrations ranging from 5000 to $500,000 / \mathrm{cu}$.ft. air.

The author is grateful to The Distillers Co. Ltd. for permission to publish this paper.

\section{REFERENCES}

DuBuy, H. G., Hollaknder, A. \& Lackey, M. D. (1945). A comparative study of sampling devices for airborne micro-organisms. Publ. Hlth Rep. Wash. suppl. no. 184 .

HAAS, G. J. (1956). The use of the membrane filter in the brewing laboratory. Wallerstein Labs. Commun. 19, 7.

Higgins, M. (1950). Comparison of the recovery rate of organisms from cotton-wool and calcium alginate wool swabs. Mon. Bull. Minist. Hlth Lab. Serv. p. 50.

Humphrey, A. E. \& Gaden, E. L., JR. (1955). Air sterilization by fibrous media. Industr. Engng Chem. 47, 924.

Richards, M. (1955). A water-soluble filter for trapping airborne micro-organisms. Nature, Lond. 176, 559.

(Received 13 March 1958) 